Aeromagnetic, Bouguer Gravity, and

Generalized Geologic Studies of the

Great Falls-Mission Range Area,

Northwestern Montana

GEOLOGICAL SURVEY PROFESSIONAL PAPER 726-A 


\section{Aeromagnetic, Bouguer Gravity, and Generalized Geologic Studies of the Great Falls-Mission Range Area, Northwestern Montana}

By M. DEAN KLEINKOPF and MELVILLE R. MUDGE

GEOPHYSICAL FIELD INVESTIGATIONS

GEOLOGICAL SURVEY PROFESSIONAL PAPER 726-A

Interpretation of aeromagnetic and gravity anomalies in terms of fault tectonics, basement rock units, and regional geology

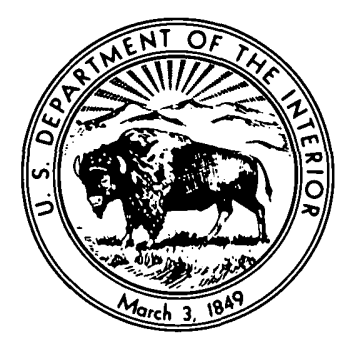




\section{UNITED STATES DEPARTMENT OF THE INTERIOR}

ROGERS C. B. MORTON, Secretary

\section{GEOLOGICAL SURVEY}

V. E. McKelvey, Director

Library of Congress catalog-card No. 73-184625

For sale by the Superintendent of Documents, U.S. Government Printing

Office Washington, D.C. 20402

Stock Number 2401-2075 


\section{CONTENTS}

\begin{tabular}{|c|c|c|}
\hline & Page & \\
\hline 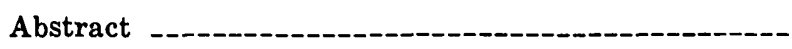 & A1 & Geophysical studies \\
\hline Introduction & 1 & Field measurements - \\
\hline General geology -_- & 2 & Rock properties \\
\hline & & Magnetic field configuration \\
\hline Geologic structure & 6 & Gravity field configuration \\
\hline Precambrian rocks - & 6 & Interpretation of geophysical data \\
\hline Paleozoic and Mesozoic rocks & 7 & Structure section \\
\hline Mesozoic and early Cenozoic igneous activity ---- & 8 & $\begin{array}{l}\text { Conclusions } \\
\text { References cited }\end{array}$ \\
\hline
\end{tabular}

\section{ILLUSTRATIONS}

[Plates are in pocket]

Plate 1. Generalized geologic and aeromagnetic map of the Great Falls-Mission Range area.

2. Complete Bouguer gravity map of the Great Falls-Mission Range area.

3. Structure section and magnetic and gravity profiles across the Great Falls-Mission Range area.

Figure 1. Index map of study area

2. Generalized chart of rock-stratigraphic units 


\title{
GEOPHYSICAL FIELD INVESTIGATIONS
}

\section{AEROMAGNETIC, BOUGUER GRAVITY, AND GENERALIZED GEOLOGIC STUDIES OF THE GREAT FALLS-MISSION RANGE AREA, NORTHWESTERN MONTANA}

\author{
By M. Dean Kleinkopf and Melville R. Mudge
}

\begin{abstract}
Aeromagnetic and gravity data provide new information on the structural framework and the distribution of nearsurface crystalline rocks in northwestern Montana.

A variety of trends and anomaly types in the magnetic data reflect the diverse geology of the area. Complex magnetic patterns of the Great Plains are attributed to a heterogeneous crystalline basement, which is probably a metamorphic complex of schist and gneiss with numerous magnetite-rich intrusives. In addition to the well-known Scapegoat-Bannatyne trend of northeast-alined fractures, the magnetic and gravity data suggest two other parallel trends of suspected fracturing and possible faulting of the crystalline basement. One northeast trend extends from Brown Sandstone Peak to near Brady; the other extends from Stonewall Mountain Lookout Station to Power. Northand northwest-trending Tertiary structures in the mountains are indicated by the gravity and magnetic data as high gradient zones. Gravity minimum anomalies coincide with downthrown fault blocks of the Swan River valley and the valley of the South Fork of the Flathead River.

Fractures along the Scapegoat-Bannatyne trend may have been the loci for emplacement of two concealed batholithic masses, one near Scapegoat Mountain and the other just north of Augusta. Similar batholithic masses are inferred also beneath the Redhead Peak-Larch Hill area and the eastern part of the Swan Range.

Prominent positive magnetic anomalies are in the southern part of the area. Some reflect exposed quartz monzonite or somewhat more mafic stocks. Similar isolated magnetic anomalies are in areas where igneous rocks are not exposed, but these anomalies probably reflect near-surface intermediate stocks. A large positive anomaly lies east of the stocks. It may indicate a gabbroic mass at a depth computed to be about 6,000 feet. The Adel Mountain volcanic field produces a distinctive complex magnetic pattern.

Plutons along a structure section are inferred, on the basis of computer model studies, to be in, and slightly above, the crystalline basement. The model that best agrees with the gravity and magnetic data shows the basement to be deep, with an irregular surface and with the plutons projecting up into the lowermost Belt sedimentary rocks.
\end{abstract}

\section{INTRODUCTION}

Aeromagnetic and gravity interpretations were made in conjunction with regional structural and stratigraphic studies of part of the northern Rocky Mountains and Great Plains in northwestern Montana (fig. 1). The purpose of the study was to provide information about the regional structural framework of the area and the distribution of near-surface igneous rocks. The area extends northwest of the Big Belt Mountains about 90 miles and west of Great Falls about 135 miles to the South Flathead valley. The data coverage extends across the South arch of the Sweetgrass arch; the Sawtooth, Lewis and Clark, Swan, Mission, and Garnet mountain ranges; and several mining districts in the Lincoln area. Earlier geological and geophysical studies of the southeastern part of the Lewis and Clark Range which were modified in the compilation of plate 1 follow: Barnett (1916) ; A. F. Bateman (written commun., 1967, unpub. data) ; Bierwagen (1964); Clapp (1932); C. F. Deiss (unpub. data) ; C. F. Deiss and C. H. Clapp (unpub. data) ; Dobbin and Erdmann (1955); Fox (1966) ; J. L. Funk (written commun., 1967), unpub. data); Gwinn (1961) ; Harrison, Reynolds, Kleinkopf, and Patee (1969) ; Holcombe (1963) ; Johns (1964) ; Kleinkopf and Mudge (1968); Kleinkopf, Mudge, and Harrison (1968); Lange (1963) ; Lyons (1944); McGill and Sommers (1967); Melson (1964); Mudge $(1965 ; 1966 a, b, c ; 1967 ; 1968)$; Mudge, Robinson, and Eaton (1966); Mudge, Erickson, and Kleinkopf (1968) ; H. J. Prostka (written commun., 1967; unpub data); G. D. Robinson and W. B. Myers (written commun., 1967 ; unpub. data) ; Ross, Andrews, and Witkind (1955); Schmidt (1963); Schmidt, Swanson, and Zubovic (1964); R. G. Schmidt (written commun., 1967; unpub. data); Sommers (1966); Stebinger (1918); Viele (1960); and Viele and Harris (1965). The areas of plate 1 not covered by the above maps have been covered by either ground reconnaissance or aerial photo- 


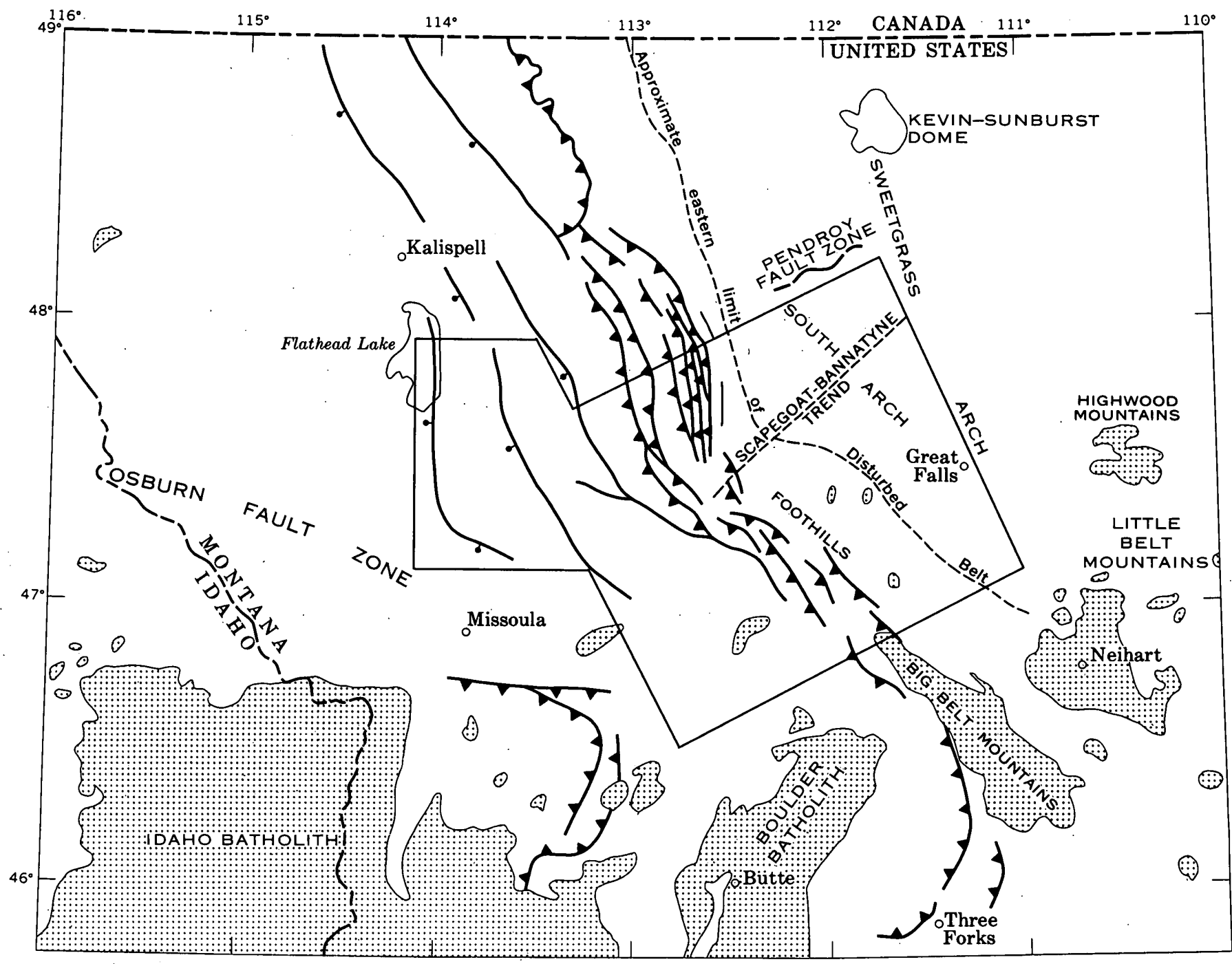

o

50 MILES

Figure 1.-Map showing relation of the study area to major geologic features in northwestern Montana. Thrust faults indicated by sawteeth (on upper plate), normal faults, by bar and ball (on downthrown side).

graph interpretation. The broad regional aspects of the gravity data have been discussed by Smith (1970). The Boulder batholith, on which an aeromagnetic survey was made by Johnson, Henderson, and Tyson (1965), joins the study area on the south, near the Blackfoot mining district.

The authors thank the many persons who have contributed to this project. Many of the gravity data were made available through the courtesy of the 1381st Geodetic Survey Squadron, Air Photographic and Charting Service, U.S. Air Force. Thanks are given to many U.S. Geological Survey colleagues for their assistance. G. P. Eaton and D. L. Peterson prepared the Bouguer gravity map from Air Force data. D. L. Peterson also made ad- ditional gravity measurements in the field. A. F. Bateman and his staff provided the borehole data shown on plate 1 . Most of the geologic data for the southeast corner of the area was prepared by Robert George Schmidt; some were provided by G. D. Robinson and W. B. Myers. The geologic data for the southwest corner were taken from a compilation by H. J. Prostka. A preliminary geologic map of the area northeast of Lincoln was kindly supplied by J. L. Funk, who was at the time of the study affiliated with the University of Missouri.

\section{GENERAL GEOLOGY}

The area shown on plate 1 encompasses the eastern part of the northern Rocky Mountains and the 
western part of the Great Plains. It includes major Basin-and-Range-type fault blocks to the west, part of the disturbed belt, and the southern part (the South arch) of the Sweetgrass arch to the east. The outcropping sedimentary rocks range in age from Precambrian (Belt) to Quaternary. The central part of the area is complicated by numerous thrust faults, some folds, and large normal and small transverse faults. The southern part of the area is complicated by effects of the complex igneous activity during the Late Cretaceous and Tertiary, when the sedimentary rocks were intruded by a variety of igneous rocks-sills, stocks, dikes, and possibly laccoliths-and in part were covered by volcanic debris of various ages. A variety of metallic mineral deposits-the most valuable, gold, silver, lead, zinc, and copper-are found in the mapped area (pl. 1). Most deposits are in or near plutons. The mining districts and some of the outlying mines are discussed in detail by Pardee and Schrader (1933) and partly by Sahinen (1959, p. 136), and therefore they will not be discussed here.

Figure 2 is a generalized chart showing the rockstratigraphic units in the area and their correlations as used by various authors. Overlap, facies change, and intertonguing stratigraphic relations are merely suggested, and the time span of each formation is shown only in a general way. The widespread unconformities are shown on the chart, whereas the local unconformities within units have been omitted. The descriptions of the rock units are given by the authors cited for each of the areas and are not repeated here.

The tectonic framework in which the Precambrian and Paleozoic sediments were deposited is illustrated by Sloss $(1950$, figs. 1,3$)$ and by McMannis (1965, p. 1806) and is discussed by Mudge (1970). The western part of the study area was the eastern part of the Cordilleran geosyncline in which clastic and carbonate sediments were deposited in shallow seas. The southern part of the area was in the Central Montana trough (Sloss, 1950, p. 427-428). Much, if not all, of the Sweetgrass arch area may have been positive during Precambrian Belt sedimentation. The pronounced eastward thinning of the Belt rocks in the disturbed belt is discussed by McGill and Sommers (1967), Mudge (1970), and several earlier authors. If Belt sedimentary rocks were deposited over the arch, as suggested by Sloss $(1950$, p. 430), they would have been extremely thin. The arch and nearby areas were uplifted and eroded before being inundated by the Middle Cambrian sea.
During Paleozoic sedimentation the eastern part of the area was probably part of the craton as suggested by Sloss (1950, fig. 1), and the Cordilleran miogeosyncline probably lay to the west. To the south a narrow zone of thicker Paleozoic sedimentary rocks that were deposited in the Central Montana trough trends east (Sloss, 1950, fig. 1 and p. 426).

The tectonic pattern of the Mesozoic probably began during Middle Jurassic; at that time the western part of Montana was a marine basin (Imlay, 1957, p. 471). The Sweetgrass arch area was a broad low uplift in the marine basin that was just below sea level (Cobban, 1945, p. 1286-1287). Later, the area was exposed, eroded, and again inundated by marine water. In Late Jurassic time the sea retreated and continental deposition followed (Cobban, 1945, p. 1290). Cretaceous sedimentation occurred in both nonmarine and marine environments. During this period, westernmost Montana was a highland that shed much detritus to the east (Reeside, 1957, p. 505-506). The thickest sediments accumulated in the western and southwestern parts of the outcrop area. During Early Cretaceous, the eastern edge of this highland may have extended into or near the present Lewis and Clark Range (Mudge and Sheppard, 1968). Plutonism, volcanism, and tectonism very likely began in Late Cretaceous time in the southern part of the area inasmuch as similar events occurred in the Boulder batholith region to the south as described by Robinson, Klepper, and Obradovich (1968). At the close of the Mesozoic, regional uplift resulted in doming and broad folding (Erdmann, 1944).

The events of the Cenozoic caused the landscape of today. The last major orogeny occurred during the early part of the Tertiary. Uplift of the western part of Montana may have caused a slide mass to move eastward across the Mesozoic basin to form a northeastward-trending belt of closely spaced thrust fau'ts, some longitudinal normal faults, and many folds (Mudge, 1970). To explain similar structures in Alberta, Canada, Price and Mountjoy (1970) provide an alternate hypothesis of lateral gravitational spreading from a zone of upwelling in the hot, mobile, metamorphic infrastructure of the core of the eastern Cordillera. The large normal faults in the western part of the mapped area (pl. 1) may have formed during or shortly after thrusting. Erosion, sedimentation in the intermontane basins, volcanism, and local plutonism took place in middle and late Teritary. Multiple periods of glaciation, 


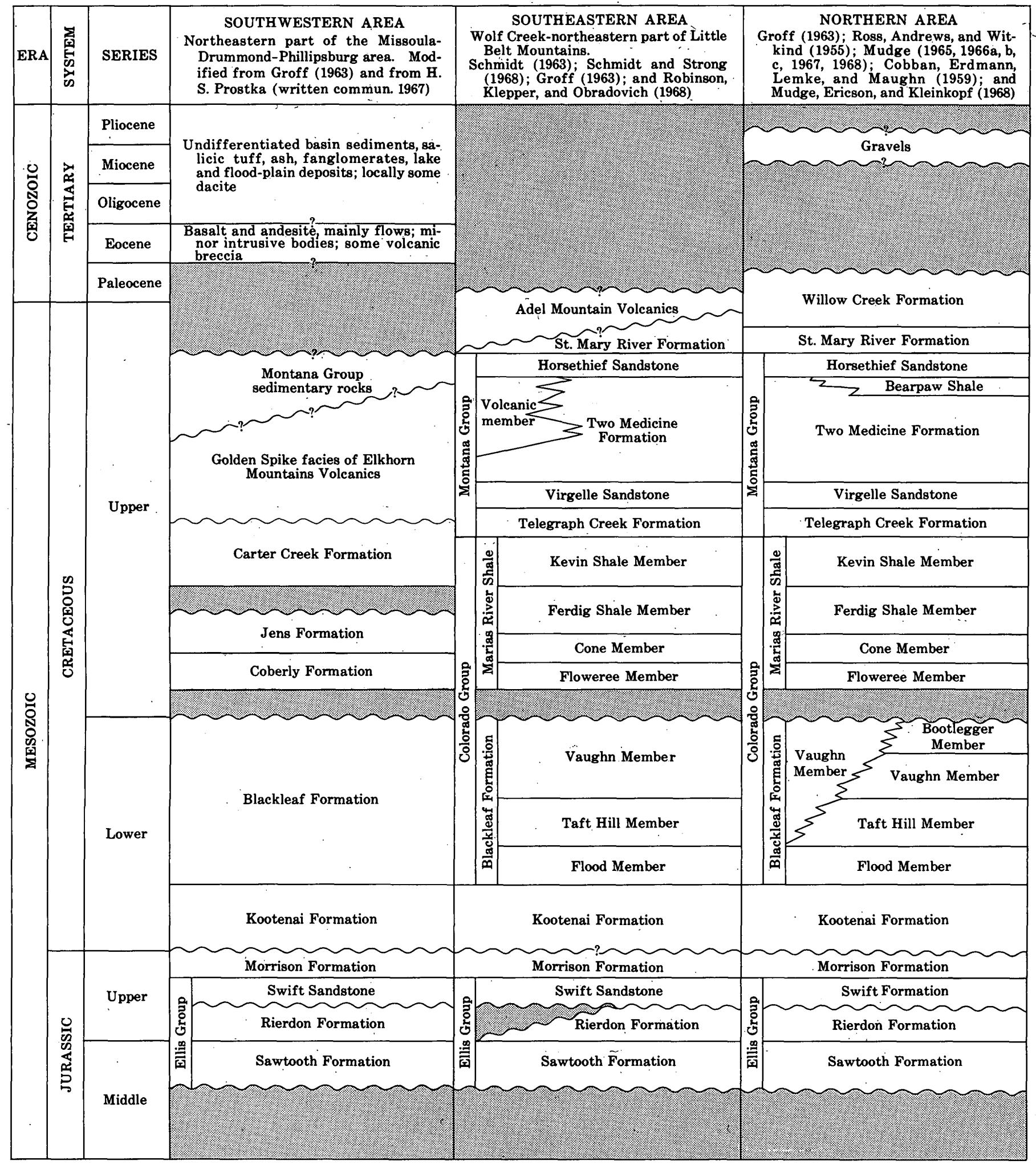

FIGURE 2.-Generalized chart 


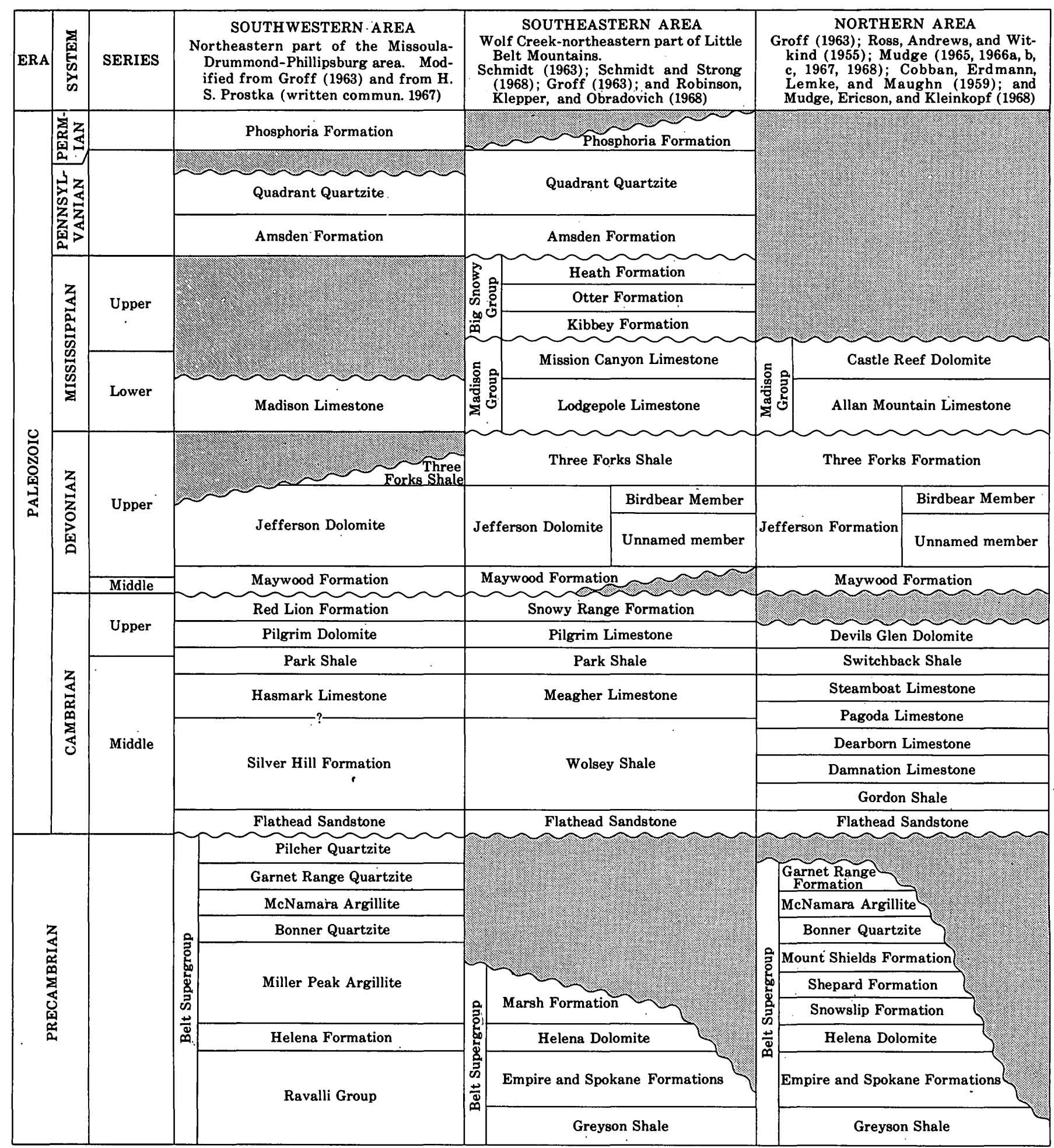

of rock-stratigraphic units. 
erosion, and sedimentation characterized the Quaternary.

\section{PRECAMBRIAN ROCKS}

Precambrian metamorphic and igneous rocks underlie the eastern part of the area, whereas Precambrian sedimentary rocks are exposed in the western part. Metamorphic and igneous rocks constitute the basement beneath Paleozoic rocks in the South arch of the Sweetgrass arch (Alpha, 1955a, b). These rocks, known from seven boreholes, range from gneissic granite, granitic gneiss, and quartz diorite to diabase, trachyandesite porphyry, and porphyritic andesite. The top of the basement is from 3,300 to 4,200 feet beneath the surface (Alpha, 1955a) and is within a broad anticline, as shown by Dobbin and Erdmann (1955).

The composition of the older Precambrian rocks in the western part of the map area is not known. Such rocks are not exposed and have not been penetrated by drilling. We assume that they are similar to the rocks in the basement in the Sweetgrass arch and to the gneiss and schist that locally have been intruded by the diorite exposed in the Little Belt Mountains (Weed, 1899) just southeast of the area shown on plate 1 .

All Precambrian rocks that are exposed in the area belong to the Belt Supergroup. The Belt consists of slightly metamorphosed sedimentary rocks; locally, they are intruded by many sills and a few dikes of diorite that are Precambrian.

The Belt rocks consist of fairly thick clastic units and one moderately thick carbonate unit that were deposited in very shallow marine waters. Although this sequence does not change markedly in lithology in the area, it does vary considerably in thickness. The exposed strata are about 20,000 feet thick in the southern part of the Mission Range (Harrison and others, 1969), as much as 23,000 feet thick in the Swan Range (Walcott, 1906), 15,000-17,000 feet in the Lincoln area, and 5,000-7,500 feet in the southern part of the Lewis and Clark Range (Mudge and others, 1968), and they are absent from the Sweetgrass arch (Alpha, 1955a). The variation in thickness is partly a result of depositional thinning of the units to the southeast and to the east and partly of deep pre-Middle Cambrian erosion in the eastern part. In those areas the Flathead Sandstone was deposited on an erosional surface in which successively older strata had been truncated to the east (Deiss, 1935, pl. 8; Mudge, 1971). To the west near the Continental Divide, the Flathead overlies the Garnet Range Formation, whereas in the easternmost exposure of the Flathead in the Dearborn River canyon, it overlies the Greyson Shale, a stratigraphic difference of at least 8,500 feet (fig. 2).

The erosional edge of the Belt rocks is very likely at, or near, the eastern edge of the disturbed belt, as shown on plate 1. Its position is inferred from the rate of eastward thinning of Belt rocks-the amount of pre-Middle Cambrian erosion of the Belt rocks-and from the knowledge that the Belt rocks are absent from the Sweetgrass arch. A distance of 46 miles separates the westernmost well that bottoms in the Precambrian crystalline rocks in the arch from the Belt outcrop in the Dearborn River canyon.

Sills and one or more dikes of diorite intrude various Belt rocks in the western part of the area (pl. 1). The sills are as much as 900 feet thick. In the southern part of the Swan Range they intrude the Spokane Formation, but northward they rise and cut across about 10,000 feet of strata to the Snowslip Formation. Similar positioning of the sills was observed in the eastern part of the Lewis and Clark Range by Mudge $(1966 \mathrm{~b}, \mathrm{c})$. In the northern part of that range, sills are emplaced in units as young as the Mount Shields Formation. The only dike observed in the eastern part of the area transects the Greyson Shale in the Dearborn River canyon. The age of the diorite has been determined by potassium-argon methods as $750 \pm 25$ m.y. (million years) by J. D. Obradovich (oral commun., 1966). The igneous rocks may be correlative with some of the buried igneous rocks on the Sweetgrass arch.

\section{PALEOZOIC AND MESOZOIC ROCKS}

Sedimentary rocks of the Cambrian, Devonian, Mississippian, Pennsylvanian, and Permian Systems of the Paleozoic Era, and the Jurassic and Cretaceous Systems of the Mesozoic Era crop out in the area (pl. 1). Pennsylvanian and Permian rocks crop out only in the southern part (fig. 2). Clastic rock (Willow Creek Formation) of Late Cretaceous and Paleocene age is present east of the Dearborn River canyon (Viele and Harris, 1965, p. 412).

The Paleozoic rocks are about 3,100 feet thick in the north-central part of the area, about 4,100 feet in the northwestern part, and about 5,100 feet in the southwestern part. The lower and middle parts of the section consist typically of very thick sequences of carbonate rock that alternate with thin sequences of clastic rock. The upper part of the section is clastic rock and thin beds of carbonate rock.

The Mesozoic rocks have an aggregate thickness 
of about 9,200 feet in the north-central outcrop area, 12,100 feet in the northwestern part, and 16,700 feet in the southwestern part. They typically are thick sequences of mudstone interbedded with thin sequences of sandstone and some conglomerate.

MESOZOIC AND EARLY CENOZOIC IGNEOUS ACTIVITY

Igneous activity in, and adjacent to, the area began early in Cretaceous time and continued periodically through the Tertiary. The activity is represented in part by sedimentary rocks derived from igneous rocks in, or adjacent to, the area and in part by igneous rocks exposed in the area. Most of the intrusive and extrusive rocks are exposed in the southern part. Many of them are probably genetically related to similar rocks in the Boulder batholith area (Robinson and others, 1968). The sequence of igneous events is as follows, from oldest to youngest:

1. Very Late Jurassic or earliest Cretaceous (Aptian) extrusive and shallow intrusive activity in or near the study area. Indicated by pebbles and cobbles of granite, quartz monzonite, granodiorite, and quartz diorite, as well as silicic lava and tuff, in the conglomerate locally present in the lower and upper parts of the Kootenai Formation in the southern part of the Sawtooth Range (Mudge and Sheppard, 1968).

2. Late Early Cretaceous (Albian) volcanic activity in or near the study area. Indicated by dacite and rhyolitic welded-tuff pebbles and cobbles and volcanic-rich sedimentary rocks, including tuff which contains accretionary lapilli locally, in the Vaughn Member of the Blackleaf Formation in the southern part of the Sawtooth Range (Mudge and Sheppard, 1968).

3. Late Cretaceous

A. Two Medicine (early Campanian) volcanic activity. Volcanic-rich sedimentary rocks, tuff, and rhyodacite and latite lavas in the lower part of the Two Medicine Formation in the Wolf Creek-Dearborn River area (Viele and Harris, 1965; Schmidt and Strong, 1968; Schmidt, 1963; Schmidt and others, 1964). These rocks are equivalent, at least in part, to the Elkhorn Mountains Volcanics of the Boulder batholith region, as described by Klepper, Weeks, and Ruppel (1957, p. 31) ; Smedes (1966, p. 21) ; and Robinson, Klepper, and Ob- radovich $(1968$, p. 563, 566-569). Pebbles of dacite and andesite lava are in conglomerate in the lower, middle, and upper parts of the Two Medicine (Mudge and Sheppard, 1968).

B. Emplacement of the Boulder batholith and its satellites (much of Campanian and early Maestrichtian; 78-68 m.y.; Tilling and others, 1968, p. 687; Robinson and others, 1968); emplacement of granodiorite and quartz monzonite (Klepper and others, 1957; Knopf, 1963; Smedes, 1966). The Marysville granodiorite stock has been dated as 78 m.y. by Baadsgaard, Folinsbee, and Lipson (1961, p. 697). The Blackfoot, Granite Butte, Silver Bell, McClellan Gulch, and other nearby stocks probably were emplaced at the same time.

C. Horsethief volcanic activity (late Campanian). Pebbles and cobbles of porphyritic trachyandesite and andesite in the Horsethief Sandstone in the vicinity of Augusta and Sun River (Viele and Harris, 1965, p. 411; Mudge and Sheppard, 1968).

D. Intrusion of trachyandesite, syenite, and diorite sills, dikes and irregularly shaped bodies in Lower Cretaceous rocks in the southeastern part of the area and in the Sawtooth Range (possibly late Maestrichtian or early Paleocene) (Gwinn, 1961; Mudge, 1966a, b, c, 1967).

E. Adel Mountain Volcanics and related intrusives (late Maestrichtian or possibly Paleocene) that cover an area about 32 miles long and as much as 18 miles wide (Lyons, 1944; Schmidt and Strong, 1968; Schmidt, 1963; Schmidt and others, 1964; Fox, 1966). They consist of about 3,200 feet of potash-rich volcanics and related intrusives, which are dikes, sills, and stocks mainly of trachybasalt, syenogabbro, and monzonite (Lyons, 1944).

4. Tertiary

A. Deposits of Eocene age in southwestern part of the area. Basalt and andesitic flows; some volcanic breccia, minor intrusive bodies, and numerous mineralized veins (H. J. Prostka, written commun., 1967). 
B. Deposits of Oligocene, Miocene, and Pliocene age in the southwestern part of the area. Rhyolite, dacite, welded tuff, latitic flows, and porphyritic intrusions (Gwinn, 1961 ; Bierwagen, 1964; Melson, 1964 ; H. J. Prostka, written commun., 1967).

C. Emplacement of Haystack Butte intrusive, southeast of Augusta (Miocene, 20 \pm 3 m.y., J. D. Obradovich, written commun., 1969). Rhyodacite porphyry that resembles a volcanic plug.

GEOLOGIC STRUCTURE

The map exhibits three major structural features: the Sweetgrass arch in the northeastern part, the disturbed belt in the central part, and the large normal faults in the western part (pl. 1). They all formed during the Cenozoic. Some older structural events are evident from the many unconformities shown in figure 2. The early Tertiary orogeny consisted of folding, thrust faulting, and normal faulting; it probably occurred between Paleocene and late Eocene (Russell, 1951; Bossort, 1957; Mc Mannis, 1965; Bally and others, 1966; Price and Montjoy, 1970). The large normal faults in the western part of the area may represent a distinct stage of Cenozoic orogeny that has been dated in nearby areas to have begun in the Oligocene and to have climaxed in the Pliocene (Pardee, 1950, p. 360 ; Russell, 1951, p. 69; Cook, 1960, p. 199). Some of the faults possibly have had recurrent movements on them throughout the Pleistocene (Mansfield, 1923, p. 269).

The disturbed belt in northwestern Montana, as defined by Mudge (1970) and used herein, is the area of intense deformation that extends from the central part of the Lewis and Clark Range to about Augusta, Mont. (pl. 1). This definition differs from that of Stebinger (1918) and Alpha (1955b, p. 137), who defined the west edge of the Belt as the mountain front. They defined the east edge as it is used in this report.

The disturbed belt contains two distinct types of structural features (Mudge, 1970). In the western part (Lewis and Clark Range) large widely spaced low-angle thrusts and large longitudinal normal faults displace Precambrian and Paleozoic rocks. In the eastern part (Sawtooth Range and western Great Plains) the thrust faults are relatively small and closely spaced, and they form a broad imbricate zone. The western Great Plains are characterized by folds with a few very small thrust faults. In the northern part of the map area these structural features trend almost north, but in the southern part they trend northwest.

The Sweetgrass arch is a broad northwest-plunging flexure with two echelon structural featuresthe South arch and Kevin-Sunburst dome (Alpha, 1955b, p. 138; Dobbin and Erdmann, 1955). Only the South arch is present in the area shown on plate 1. This arch has been an active tectonic feature at various times from the Precambrian to the present, but it achieved its present size and configuration largely during the early Tertiary orogeny (Alpha, 1955a, b).

The Scapegoat-Bannatyne trend is a northeastward-trending series of structural anomalies that were first recognized by Dobbin and Erdmann (1955) and discussed by Alpha (1955a). As shown on plate 1, its southwest terminus is in a transverse fault zone that displaces thrust faults. As discussed by Alpha (1955a, p. 133), this trend parallels the structural grain of the pre-Paleozoic and early $\mathrm{Pa}$ leozoic features of the Canadian Shield in Canada and Minnesota and the pre-Paleozoic structural fabric in the subsurface in central and eastern Montana and in North Dakota. The Pendroy fault zone, at the north end of the South arch (fig. 1), has a similar orientation.

On the Sweetgrass arch the Scapegoat-Bannatyne trend is marked by high areas on the Precambrian surface against which the Cambrian and basal Devonian rocks wedge out; these areas have a known relief of more than 1,400 feet (Alpha, 1955a, p. 133). The higher parts of the trend were subsequently raised probably during pre-Jurassic, Late Cretaceous, and early Tertiary times.

The north-trending Augusta syncline, just northwest of Augusta, lies west of the Sweetgrass arch, across the eastern part of the disturbed belt (Alpha, 1955b). The west side of the syncline contains numerous small folds and some small faults (Stebinger, 1918, pl. 24). The east side forms the west flank of the Sweetgrass arch.

In the southwestern part of the area there are numerous southeast-plunging folds not shown on plate 1 that are along the Montana lineament, as discussed by many authors, including Calkins and Jones (1931) ; Clapp (1932) ; Langton (1935) ; Poulter (1959); Gwinn (1961); and McMannis (1965).

The largest normal faults in the western part of the area are along the east side of the Swan River valley (Swan fault) and the east side of the South Fork of the Flathead River (pl. 1). The displace- 
ment of the Swan fault is probably more than 20,000 feet. The displacement of the South Fork Flathead fault is about 16,000 feet (Sommers, 1966, p. 84).

The Mission Range, at the western edge of the map area, is a structurally simple range of blockfault mountains (Harrison and others, 1969). The block is bounded on the west by the northwardtrending Mission fault and on the east by the north-northwest-trending Swan fault (pl. 1). The block is tilted eastward at about $25^{\circ}$; this tilting results in a homoclinal dip from the crest of the range eastward into Swan River valley. A large monoclinal flexure at the range crest flattens the beds to the west, where they have been dragged down to about horizontal on the footwall of the Mission fault.

Most of the northeast-trending faults in the west-central part of the area are tear or transverse faults; some are normal faults. The northeast-trending faults are younger than the thrust faults, and their strike is virtually parallel to the ScapegoatBannatyne trend; similar faults in the western part of the area are undated.

\section{GEOPHYSICAL STUDIES}

\section{FIELD MEASUREMENTS}

The total intensity aeromagnetic data shown on plate 1 involved two surveys. One survey of about 7,800 square miles was flown in a northeast-southwest direction with traverses spaced about 2 miles apart. A smaller survey on the west, which covered about 1,800 square miles of the Swan and Mission Ranges, was flown east-west at a flight line spacing of about 1 mile. The data from the smaller survey have been used in geologic studies of the Mission Mountains primitive area by Harrison, Reynolds, Kleinkopf, and Pattee (1969). Both surveys were flown at a barometric elevation of 9,000 feet, with deviations to 10,500 feet for clearance of mountain peaks. Measurements were made with a continuously recording $\mathrm{ASQ}-10$ fluxgate magnetometer installed in a Convair airplane.

Topographic maps were used for position control. The flight paths were recorded by a gyrostabilized 35-mm continuous-strip camera (Evenden and others, 1967). Flight paths were recovered by Doppler navigation for the survey over the Swan and Mission Ranges. Base lines, which were closed on themselves, were flown normal to the traverse lines for correction of diurnal and instrumental drift. The calibration of the magnetometer was maintained by frequent comparisons with a proton magnetometer.
The total intensity data were reduced to an arbitrary datum at a contour interval of $20 \gamma$ (gammas). The overall precision of the magnetic map is estimated to be about $5 \gamma$.

Gravity data for 430 stations were obtained through the courtesy of the Air Force, and 125 supplemental points were set by the U.S. Geological Survey (pl. 2). The gravity measurements were adjusted to the absolute datum of the Woollard (1958, p. 533) airport base, station WA124, at Great Falls, Mont. The data were reduced to complete Bouguer gravity values by use of an assumed rock density of $2.67 \mathrm{~g} / \mathrm{cm}^{3}$ (grams per cubic centimeter). The contour interval of $5 \mathrm{mgal}$ (milligal) seems to be realistic for most of the area. Terrain corrections were made through the $\mathrm{H}$ zone of Hammer (1939) with hand templates and out to $167 \mathrm{~km}$ (kilometer) by means of a digital computer (Plouff, 1966).

Many of the gravity stations in the mountains were reached by helicopter, and the elevations at the stations were determined by altimetry or by estimates made from topographic maps-such elevations may be in error by 50-100 feet. Most station elevations on the plains where U.S. Geological Survey or U.S. Coast and Geodetic Survey bench marks are used for reference are probably accurate to 1 foot. Consequently, the accuracy of the Bouguer gravity map is estimated to vary from less than 1 mgal on the plains to $6 \mathrm{mgal}$ in the mountains.

\section{ROCK PROPERTIES}

Magnetic susceptibility and density data were obtained from 22 samples analyzed in the laboratory and from data on similar rock types in surrounding areas (M. R. Klepper, written commun., 1969; Burfeind, 1967; Davis and others, 1965). The density and susceptibility values used in the interpretations are assumed averages for the whole area and should be considered only approximations for specific problem areas.

Rock densities are assumed to average from 2.7 to $2.8 \mathrm{~g} / \mathrm{cm}^{3}$ for the Precambrian Belt and Paleozoic rocks, $2.6 \mathrm{~g} / \mathrm{cm}^{3}$ for Mesozoic rocks, and $2.3 \mathrm{~g} / \mathrm{m}^{3}$ for Cenozoic rocks. The Precambrian diorite sills are about $2.9 \mathrm{~g} / \mathrm{cm}^{3}$ (Harrison and others, 1971). Knopf (1963) reported an average density of 2.66 $\mathrm{g} / \mathrm{cm}^{3}$ for the Upper Cretaceous Priest Pass Leucomonzonite mass at the north end of the Boulder batholith. Values of $2.7-2.8 \mathrm{~g} / \mathrm{cm}^{3}$ seem to be the range for the Upper Cretaceous granodiorite stocks in the southern part of the area (Knopf, 1963).

The magnetic susceptibility measurements show significant differences of magnetic properties among 
the various crystalline rock types. On this basis, these rocks could be expected to produce detectable magnetic anomalies. In laboratory determinations, the Tertiary trachyandesite sills show an average value of $0.001 \mathrm{emu} / \mathrm{cm}^{3}$ (electromagnetic units per cubic centimeter), whereas the Precambrian diorite-gabbro sills average about $0.003 \mathrm{emu} / \mathrm{cm}^{3}$. Samples of granodiorite from the Boulder batholith average $0.0058 \mathrm{emu} / \mathrm{cm}^{3}$. Quartz monzonite varies from 0.0008 to $0.002 \mathrm{emu} / \mathrm{cm}^{3}$; gabbro is near 0.0024 $\mathrm{emu} / \mathrm{cm}^{3}$. A magnetic susceptibility range of $0.006-0.008 \mathrm{emu} / \mathrm{cm}^{3}$ for intrusive rocks in the Three Forks region to the south was determined by Davis and others (1965), by means of a field method described by Hyslop (1945).

\section{MAGNETIC FIELD CONFIGURATION}

The first-order relief across the magnetic map from northeast to southwest is about $1,000 \gamma$; this relief reflects the southwest-dipping gradient of the earth's normal field of about $7 \gamma$ per mile. The northwest trend of the regional magnetic strike is locally deflected to the north by major early Tertiary structural trends. Some of the large normal and thrust faults shown on plate 1 , for example, those along the west side of the Mission Range and those along the east side of the Sawtooth Range, are represented by high magnetic gradient zones. The complexities of the magnetic field over the Great Plains are exhibited by diverse trends and by variations in anomaly shapes and sizes. Northwest, north-northwest, and northeast alinements are evident in the magnetic patterns. These alinements contrast markedly with expressions over the mountains, where the more gentle gradient zones are distorted mainly by shorter wavelength anomalies that have been produced by igneous intrusives. Sharp high-amplitude positive and negative anomalies are characteristic of the igneous rocks of the Adel Mountain volcanic field.

\section{GRAVITY FIELD CONFIGURATION}

The regional gravity field dips to the southwest at about $1 \mathrm{mgal}$ per mile, within a 100-mgal range of $-80 \mathrm{mgal}$ over the Great Plains to $-180 \mathrm{mgal}$ over high topography in the southwestern part of the area.

The gravity field over the Great Plains (pl. 1) is dominated by a northwest-trending high-gradient zone located just east of the disturbed belt (pl. 1). The high-gradient zone is distorted by several southwest plunging maximum noses.

A large north-trending 10-mgal minimum is located just east of the Sawtooth Range. Major north-northwest-trending minima correlate with valleys of the Flathead and Swan Rivers. The edge of a broad north-south-trending zone of high-gravity gradient occurs along the major normal fault that bounds the west side of the Mission Range. Another prominent gravity feature is a nearly eastwest-trending maximum ridge of 10 - to $15-\mathrm{mgal}$ amplitude that extends west from about lat $47^{\circ} \mathrm{N}$., long $112^{\circ} \mathrm{W}$.

INTERPRETATION OF GEOPHYSICAL DATA

Magnetic data were interpreted qualitatively by gradient and configuration studies and semiquantitatively by the methods of Vacquier, Steenland, Henderson, and Zietz (1951), Zietz and Henderson (1956), and Zietz and Andreasen (1967). Remanent magnetism, where important, is assumed to be parallel to the earth's field; thus, total magnetizations (induced plus remanent) of all rocks are assumed to be everywhere parallel. The source must reflect some type of crystalline rock, inasmuch as the sedimentary rocks are nonmagnetic, except for two sandstone beds (Upper Cretaceous Virgelle and Horsethief Sandstones), which locally contain at least 30 percent magnetite but which are less than 10 feet thick. A traceable zone of high-magnetic gradient correlates with the outcrop of the Virgelle Sandstone (pl. 1).

The Bouguer gravity data are broadly spaced, and elevation control on many of the stations is poor. These data, as they relate to the magnetic interpretations, are therefore discussed only in a qualitative fashion.

The variety of trends and anomaly types in the magnetic data reflects the diverse geology of the area. The complex magnetic patterns of the Great Plains are attributed to a heterogeneous crystalline basement, probably a metamorphic complex of schist and gneiss and numerous magnetite-rich intrusions.

Depths to anomaly sources, believed to be at or near the crystalline basement level, were calculated from measurements of magnetic gradients (method of Vacquier and others, 1951). The results for the Great Plains agree within 10 percent of values obtained from a combination of structure and isopach maps. The basement sea-level datum was computed to be about $-1,000$ feet at Great Falls and $-2,500$ feet at Choteau. In the disturbed belt, the paucity of discrete magnetic gradients that could be measured with confidence prevented constructing a coherent basement surface-configuration map. 
The north- and northwest-trending early Tertiary structures in the Lewis and Clark and Sawtooth Ranges are reflected in both the magnetic data and the gravity data by high-gradient zones of varying degrees of continuity. The high-gradient zones of interest are distorted and compounded in several areas by shorter wavelength anomalies that are caused by dioritic sill complexes (pl. 1). The large magnetic anomalies labeled 21 and 22 (pl. 1) also mask definition of unique high-gradient zones that are associated with northwest structural trends.

The sills shown on the geologic map exhibit magnetic anomalies in the form of elongated short-wavelength positive and negative closures and noses of less than $100 \gamma$ amplitude. Presence of other sills, buried at shallow depths, is strongly suggested by the magnetic data. The gravity data are not of sufficient detail to reflect either the exposed sills or the buried sills. The Precambrian diorite sills give a greater magnetic response than the Upper Cretaceous or lower Tertiary trachybasalt sills. This greater response can be attributed to the greater magnetite content (as much as 15 percent) of the Precambrian diorite sills (Knapp, 1963).

The possible geologic significance of the more prominent magnetic and gravity anomalies is discussed. The geophysical data add greater subsurface definition to known geologic features and provide a basis for postulating the presence of those unknown. The following paragraph numbers are keyed to the prominent magnetic and gravity features on the maps (pls. 1,2) and are discussed in roughly counterclockwise order, beginning near Great Falls. Anomalies numbered 18, 21, 22, and 38 are the same anomalies referred to as numbers 14, 10, 11, and 5, respectively, in an earlier report by Mudge, Erickson, and Kleinkopf (1968).

1. The complex magnetic patterns of the Great Plains, north and west of Great Falls, are attributed to a heterogeneous crystalline basement, presumably of Precambrian schist and gneiss like that near Neihart in the Little Belt Mountains (Weed, 1899). Seven wells have penetrated the basement rocks on the Sweetgrass arch and Kevin-Sunburst dome. The rocks are gneissic granite, granite gneiss, diabase, quartz diorite, trachyandesite porphyry, and porphyritic andesite (Alpha, 1955a, p. 133-134). Two wells (sec. 12 , T. 24 N., R. 2 W.; sec. 30 , T. 25 N., R. 1 W.), between Collins and Dutton, penetrated trachyandesite porphyry. Some of the ig- neous rocks may be much younger than Precambrian.

2. A magnetic and gravity trend extending north-northwest from the north end of the Little Belt Mountains to about 35 miles north of Great Falls closely approximates the trend of the anticlinal axis that passes through Great Falls (pl. 1). The trend probably reflects an extension of the north-plunging structural features of the Little Belt Mountains. The sharpness of the magnetic trend may be the manifestation of a buried basement block uplifted on the west or a northtrending unit in the basement that has a magnetic contrast to the adjacent rocks. The persistence of the north-trending zone of high magnetic gradient is demonstrated by the fact that it terminates several east and east-northeast magnetic trends.

3. The magnetic anomalies marked $3 \mathrm{~A}$ and $3 \mathrm{~B}$ probably reflect buried plutons. The plutons are very likely of intermediate composition, inasmuch as stocks and laccoliths of such composition are exposed in the northern end of the nearby Little Belt Mountains (Weed, 1899 ; I. J. Witkind, oral commun., 1969).

4. The most pronounced northeasterly magnetic and gravity alinement is the Scapegoat-Bannatyne trend ( $\mathrm{pl} .1$ ). It is manifested in the magnetic data as a series of residual positives and northeast contour alinements. On the Great Plains, the gravity expression of the Scapegoat-Bannatyne trend is a southwest-plunging maximum nose which has a residual maximum closure of about $10 \mathrm{mgal}$ at its intersection with the axis of the South arch. The trend may have regional structural implications. The fracture system may have been the structural control for the emplacement of two magnetic anomaly sources, one about 8 miles north of Augusta (pl. 1, anomaly 18) and the other at Scapegoat Mountain in the Lewis and Clark Range (pl. 1, anomaly 21 ).

5. A northeasterly magnetic trend parallel to the Scapegoat-Bannatyne extends from Brown Sandstone Peak past the north end of the large magnetic positive at the edge of the plains to about 5 miles north of Brady. The trend is manifested in both the gravity and the magnetic data as a series of alined highs and lows and by parallelism of the contours. 
The gravity data suggest that the trend represents a basement fault that extends 10 miles northeast and southwest of Brady. The northwest side is probably upthrown.

6. About 15 miles southeast of the Scapegoat-Bannatyne trend, a northeasterly trend in the magnetic and gravity data reflects strong contour deflections and alinements. One northeast alinement along the trend is the magnetic negative whose axis passes about 12 miles southeast of Augusta. The trend extends southwest through the small magnetic closure over Cuniff Basin (anomaly 7) and Blowout Mountain to Stonewall Mountain Lookout Station. It extends east-northeast as far as the secondary axis of the South arch (pl. 1), crossing the arch near the town of Power in the form of a high-gradient zone. The trend is well indicated in the gravity data from the edge of the disturbed belt on the plains southwest to Blowout Mountain. Here, there are sufficient gravity stations to define a contour alinement.

7. The small magnetic anomaly over Cuniff Basin reflects the High Bridge stock, which, according to Viele and Harris (1965, p. 410), is a trachyandesitic to rhyodacitic mass that closely resembles volcanic pipe breccia.

8. The three small-amplitude positive magnetic residuals at Crown, Shaw, and Cascade Buttes reflect the trachyandesite sills and feeder dikes discussed by Lyons (1944) and Fox (1966). Square Butte nearby does not show a residual on the aeromagnetic map, but this is probably due to lack of data, for this butte too has a sill and feeder dike (Fox, 1966, pl. 1).

9. The northwesterly trend of magnetic contours appears to extend from anomaly 38 through Haystack Butte (anomaly 10) to anomaly 17. Three wells were drilled along this trend (pl. 1). The two westernmost wells penetrated diorite sills (?) in Cretaceous rocks. The sills (?) in the well (NE. cor. T. 18 N., R. 6 W.) northeast of Cuniff Basin are at depths of 4,410-4,650 feet, 4,670-4,715 feet, $5,170-5,320$ feet, $5,650-6,490$ feet, and from 6,580 to the bottom of the hole at 6,880 feet. In the well east of Cuniff Basin (SW. cor. T. 18 N., R. 5 W.), sills (?) were penetrated at depths of 2,490-3,120 feet, 3,460-4,420 feet, 4,920-5,340 feet, and 7,000-7,100 feet. The instrusives are very likely correlative with the sills exposed at anomaly 17. In the area between Haystack Butte (anomaly 10) and anomaly 38 there is a relatively broad band of exposed volcanics cut by sills in the Two Medicine Formation (Viele, 1960; Viele and Harris, 1965). Sills and possibly volcanic rock may be in the subsurface in the area between Haystack Butte and anomaly 17, as suggested by the northerly extension of the trend of magnetic anomaly 9 . If this is true, the igneous rocks do not extend as far east as the well (SW. cor. T. 20 N., R. 7 W.) just north of Haystack Butte, which down to a depth of 9,327 feet did not penetrate igneous rocks. Volcanic-rich sedimentary rocks of the Two Medicine Formation, however, are repeated at least 11 times by thrust faults in the upper 6,000 feet of the well, and these may contribute to the magnetic anomaly trend.

10. Haystack Butte is a prominent landmark east of the mountains that towers 1,800 feet above the plains. The butte, of rhyodacite porphyry, resembles a volcanic plug; dikes extend west and south from it (Viele, 1960, p. 146). It lies between two flight lines and is not reflected on the magnetic map. A gravity station near the southeast edge of the butte detected no anomaly, which suggests that the intrusive may be a vertical mass.

11. A high magnetic gradient zone extends from 5 miles southwest of Great Falls in a westnorthwesterly direction for 30 miles. This high-gradient zone seems to mark the buried southeastward extension of the zero edge of Belt rocks from the Sun River Canyon area (Mudge and others, 1968). The magnetiterich source for the gradient zone is unknown.

12. The positive magnetic anomalies labeled $12 \mathrm{~A}$ and $12 \mathrm{~B}$ in the northeast corner of the map area very likely reflect mafic bodies in the crystalline basement.

13. The most pronounced gravity expression on the plains is a high-gradient zone about 15 miles wide and $30 \mathrm{mgal}$ in amplitude that extends northwest from Great Falls through Choteau. The zone of high gradient is part of an extensive northwest-trending regional feature shown on the Gravity Map of the United States by Woollard and Joesting 
(1964) which may reflect an upper-crust transition between the Great Plains and the Rocky Mountains. Crustal model studies of Smith (1967) show, by means of seismic refraction and regional gravity data, that the high-gradient zone may be caused by the wedging out of high-density material in the upper crust. Inasmuch as the magnetic data show no correlative anomaly, the high-density source can be assumed to be no closer to the surface than the Curie point level (Vacquier and others, 1951).

14. A 5- to 10-mgal gravity minimum extends north-northwest for about 35 miles from Haystack Butte, along, and partly beneath, the mountain front. The minimum suggests a structural low which may be broader than that shown by Stebinger $(1918, \mathrm{pl} .1)$.

15. A fan-shaped set of magnetic anomalies reflects the complex Adel Mountain Volcanics and associated intrusive rocks. The largest anomaly within this volcanic field is about $800 \gamma$ in amplitude. It may reflect a moderately large near-surface mafic mass. The presence of numerous small intrusive bodies within the volcanics suggest that many of the other smaller anomalies are also near-surface mafic masses. The northwest-trending anomaly may reflect one or more dikes in the area, as shown by Lyons (1944). At the north end of the volcanic field, in T. 18 N., R. 3 W., there are five small syenogabbro laccoliths and associated feeder dikes (Lyons, 1944, p. 459).

16. A small northwest-trending anomaly, southeast of Augusta, is produced by a stock, possibly of syenogabbro, that correlates with the crest and north side of the maximum of the anomaly.

17. A northwest-trending anomaly in the Pretty Prairie area reflects a magnetite-rich trachyandesite sill, as much as 600 feet thick, that is folded and repeated many times by thrust faults. The sill extends north to form Sheep Reef where it dips steeply to the west and is not repeated by faulting. Near Sheep Reef it has no magnetic expression.

18. A magnetic anomaly, underlying more than six townships east of the disturbed belt and north of Augusta, probably reflects a gabbroic body at a computed depth of $6,000 \pm$ 1,100 feet below the surface (anomaly 14 of Mudge and others, 1968, p. E16). A well
(NW. cor. T. 21 N., R. 5 W.) within the area of anomaly (pl. 1) bottomed in the Steamboat Limestone (Middle Cambrian) at a total depth of 6,775 feet. The lower Paleozoic rocks probably rest unconformably on preBelt basement rocks here (Mudge and others, 1968 , p. E16), and the gabbroic body is presumably within the basement.

19. The southeast-trending noselike magnetic anomaly that extends from Deer Creel (19A) to the upper reaches of Smith Creek (19C) reflects a diorite-gabbro sill; this sill is as much as 500 feet thick and is locally repeated by thrust faults. Along Wood Canyon (19B) the sill contains as much as 15 percent magnetite (Knapp, 1963). The closed anomaly in the Deer Creek area very likely reflects repetition of the sill by thrust faults.

20. A magnetic anomaly, on the west side of the North Fork of Sun River valley, reflects the east edge of the outcropping Precambrian sedimentary rocks of the Lewis and Clark Range block and their contained sills. The minor trend depicted by the contours is probably influenced more by the sill than by the Belt rocks.

21. The magnetic anomaly southwest of Scapegoat Mountain, in the area of Concord Mountain and Evans Peak, is discussed by Mudge, Erickson, and Kleinkopf (1968, p. E15) as anomaly 10. It is interpreted to represent a buried pluton of intermediate composition at a computed depth of $10,500 \pm 1,200$ feet below the surface.

22. Magnetic anomaly 22 extends over the Redhead Peak-Larch Hill area. Mudge, Erickson, and Kleinkopf (1968, p. E15, E16, anomaly 11) believe that this anomaly reflects a large pluton at a computed depth of 9,500 $\pm 1,000$ feet.

23. Magnetic anomaly 23, in the Camp Creek Cayuse Mountain area, is of small amplitude. The anomaly is the one labeled 8 by Mudge, Erickson, and Kleinkopf (1968, pl. 2). Only Belt sedimentary rocks are exposed in the area. To the north, 1 mile east of Big Prairie Ranger station, a diorite sill, 77 feet thick, intrudes these rocks (Sommers, 1966, p. 74); this sill apparently has no magnetic expression. The anomaly may represent a buried dike or small pluton.

24. A north-trending zone of high magnetic gradient extends from Sugarloaf Mountain to 
the north edge of the map area. The zone, which is over the valley of the South Fork of the Flathead River, on the west side of the Lewis and Clark Range, may be caused by basement faulting. A normal fault of about 16,000 feet displacement has been mapped along the east side of the valley (Sommers, 1966). The gravity data are sparse, but they do show a broad 5- to 10-mgal minimum over the valley area of Paleozoic rocks, the downthrown block.

25. A large 80- $\gamma$ magnetic anomaly centered over the west edge of the Swan Range suggests a source buried about 20,000 feet $(16,000 \mathrm{ft}$ below sea level). The position of the anomaly over the Swan fault suggests the presence of a buried pluton in the Precambrian crystalline basement (pl. 3).

26. To the east of anomaly 25 , a narrow elongate 100- $\gamma$ positive anomaly on the east flank of the large anomaly reflects a highly magnetic Precambrian sill and dike complex of dioritic-gabbroic composition that crops out for several miles along the crest of the Swan Range (pl. 1).

27. The gravity minima at Swan valley probably are produced by two local sedimentary basins, one centered near the Condon Ranger station, and the other, at Seeley Lake. Near the Ranger station the Cenozoic sediments may be 2,000-3,000 feet thick, as suggested by the 10- to 15-mgal minimum. At Seeley Lake the gravity minimum is attributed to Belt rocks that are preserved along the Swan Range fault or to a buried silicic pluton that is related to the Garnet Range on the south. The total displacement of the normal fault along the east side of the valley is at least 20,000 feet (Mudge, 1970). The fault lacks gravity expression, because only Belt rocks are involved on both sides of the fault.

28. A north-trending high magnetic gradient zone, about 2 miles wide and of $80 \gamma$ amplitude, is parallel to the west edge of the Mission Range and to the large north-trending Mission fault described by Pardee (1950). The fault dips about $45^{\circ} \mathrm{W}$. and may have a displacement of as much as 17,000 feet (Nobles, 1952). The rocks exposed along the west side of the range are of the Ravalli Group (Johns, 1964; Harrison and others, 1969); exposures of igneous rocks are not recorded.
The source for the high magnetic gradient zone appears to have a maximum depth of about 1 mile. The Mission fault may have controlled the west edge of an igneous intrusion. The Mission fault was not reflected in the gravity data, inasmuch as the displacement involves only Belt rocks.

29. The southward positive nosing of the magnetic contours from lat $47^{\circ} 20^{\prime} \mathrm{N}$. to lat $47^{\circ} 30^{\prime} \mathrm{N}$., near McDonald Lake, may reflect near-surface igneous rocks. The small outcrop of Tertiary quartz diorite about 5 miles to the north along Elk Creek has no magnetic expression (Harrison and others, 1969), but quartz diorite may extend downward to the south and may attain dimensions that would produce the magnetic nosing.

30. The southeasterly trend of the magnetic contours parallels the trace of the Swan fault on the north side of Kleinschmidt Flat. This fault with the southwest side downthrown has been traced southeast as far as the Lincoln area. As shown by the trend of the contours, the fault may very likely extend beneath the younger volcanics at Stemple Pass (between anomalies 35 and 36) and connect with the normal fault shown southeast of the pass. This major normal fault may extend much farther southeast to form the north margin of Little Prickly Pear valley (G. D. Robinson, oral commun., 1969). The southeasterly trend of contours in this area is virtually parallel to the Central Montana Trough as visualized by Sloss (1950, fig. 3) and McMannis (1965, p. 1806).

31. In the Arrastra Mountain-Mineral Hill area, north of Lincoln, the southeast-trending magnetic anomaly reflects two thick dioritegabbro sills of late Precambrian age.

32. The magnetic anomaly at Dalton Mountain, a few miles east of Browns Lake, is probably caused by a buried pluton. The pluton may be related to stocks exposed along the mountain ridge, including Granite Butte. If so, the pluton may be quartz diorite to quartz monzonite.

33. Southeast of Dalton Mountain, this magnetic anomaly trends northeast along the crest of the range. No stocks are exposed in the area, but basalt and andesite are present and may be associated with a buried intrusive. 
34. The exposed quartz diorite stock at the head of McClellan Gulch (SW. cor. T. 13 N., R. 8 W.) was referred to as the Dalton Mountain stock by Melson (1964, fig. 2), but Dalton Mountain is about 13 miles to the northwest. (See pl. 1, anomaly 32.) The stock at the head of McClellan Gulch is slightly more mafic than the Silver Bell and Granite Butte stocks (Melson, 1964, p. 37). The magnetic anomaly not only includes the McClellan Gulch stock in the northern part but also extends farther west than the McClellan Gulch stock. A short distance to the north a group of small stocks mapped by Melson (1964, p. 37) do not show anomalies on the aeromagnetic map-probably because the stocks are small and are located between flight lines.

35. These closely spaced contours are over the exposed part of a granodiorite and quartz monzonite stock at Granite Butte south of Stemple Pass. The western projection of the magnetic nose includes the exposed Silver Bell stock. The lack of a more pronounced anomaly over it is possibly explained by $\mathrm{Mel}-$ son (1964, p. 36) : "the Silver Bell stock, in contrast to the Granite Peak stock; shows considerable evidence of late magmatic alteration and mineralization by water-rich volatiles."

36. The two small magnetic anomalies north of Stemple Pass and Virginia Creek may reflect buried granodiorite or quartz monzonite stocks like the Granite Butte and Silver Bell stocks. The area is overlain by $1,000-1,500$ feet of latitic to andesitic volcanic rocks, some of which is welded tuff; locally, there are rhyolite domes (Melson, 1964, p. 46). Melson (p. 46-47) noted that the volcanic rocks rest unconformably on the contact aureoles of the southern stocks.

37. The broad magnetic nose south of Rogers Pass is produced by a large diorite-gabbro porphyry sill that crops out in Shave Gulch and its tributaries, north of the Mike Horse mine (Pardee and Schrader, 1933, p. 88). Pardee and Schrader (p. 90) noted that dikes of trachyte porphyry-granodiorite and rhyolite-younger than the sill are present in the Mike Horse mine and nearby areas. A phonolite body, also younger than the sill, is just north of the mine.

38. This large magnetic anomaly is mostly east of
Rogers Pass in drainages of the Middle and South Forks of the Dearborn River. Belt and Paleozoic rocks, in large low-angle thrustfault plates, crop out over the western half of the anomalous mass. These rocks are thrust on the Two Medicine, St. Mary River, and Willow Creek Formations, which are exposed over the eastern half of the anomalous mass. Gabbro and monzonite sills and small quartz monzonite stocks are exposed near the western edge of the area of the anomaly. The anomaly is probably produced by a large mafic mass at a calculated depth of $6,000 \pm$ 1,000 feet beneath the surface (Mudge and others, 1968, p. E15).

39. This magnetic anomaly, west of Marysville, reflects the Marysville stock, which is exposed in the eastern part of the area of the anomaly. The stock of diorite intrudes the Belt rocks and has a contact aureole $1 / 2-2$ miles wide; it broadens downward into an irregular pyramidal form (Pardee and Schrader, 1933 , p. 64). The anomaly indicates that the bulk of the stock is buried south of the exposure (pl. 1).

40. This magnetic anomaly is produced by the Blackfoot stock and nearby smaller intrusives, which are quartz monzonite. The anomaly covers much more area than the exposed stock, suggesting that the intrusive complex broadens with depth.

41. The magnetic anomaly at the head of Warm Springs Creek may reflect a pluton of intermediate composition that is buried by Tertiary basalt and andesite. The western part of the anomaly is overlain by Paleozoic carbonate rock that has been altered to skarn.

42. The extensive 15-20-mgal gravity minimum which embraces the area of the stocks and circular anomalies 32-40 may represent a buried extension of the porphyritic granodiorite and (or) Priest Pass Leucomonzonite bodies (Knopf, 1963) that are exposed about 30 miles south of Lincoln near Austin. The stocks that have been described as granodiorite may be apophyses of the parent body. Barrell (1907, p. 81) suggested that stocks such as those near Marysville and Granite Butte are upward prolongations or cupolas of the northern extension of the Boulder batholith. The gravity minimum extends south over the batholith. 
Structure Section

The main geologic features of the study area are depicted on structure section $A-A^{\prime}$ (pl. 3). Profiles of the observed magnetic and gravity data, with the regional field removed, have been drawn in the same plane. The magnetic profile calculated from two-dimensional model studies is compared with the observed magnetic data. The gravity control is not of sufficient quality or detail to obtain meaningful results from modeling the complex density section which involves density contrasts in the sedimentary rocks as well as in the crystalline basement. Several of the large positive magnetic and gravity anomalies were previously interpreted as representing buried pluton masses of high magnetic and density contrasts (Mudge and others, 1966, 1968; Harrison and others, 1969). The model studies of section $A-A^{\prime}$ provide additional speculations on the possible size, shape, and depth of burial of the plutons and the configuration of the crystalline-basement surface beneath the sedimentary rocks. Through trial and error, magnetic susceptibility values of $0.0008-0.0025 \mathrm{emu} / \mathrm{cm}^{3}$ were assigned to the inferred plutons. These values fit compositions ranging from quartz monzonite through granodiorite to gabbro. The crystalline basement was assumed to be Precambrian gneissic rock similar to exposures in the Little Belt Mountains. Magnetic susceptibility values of $0.0001-0.0005 \mathrm{emu} / \mathrm{cm}^{3}$ were assigned, which suggests a low, but varying, magnetite content of the Precambrian gneiss.

The basement configuration and distribution of plutons shown in section $A-A^{\prime}$ gives a theoretical magnetic profile which is a reasonably good fit to the observed magnetic profile (pl. 3). In the west half of the section, the Precambrian basement is considered to be deeply buried, with plutons possibly projecting through it into the lower part of the Belt sedimentary rocks.

The gravity data confirm the presence of plutons postulated from the magnetic model studies. Other gravity anomalies probably have sources above the basement. For example, the gravity maximum anomaly of about $6 \mathrm{mgal}$ over the eastern Sawtooth Range is attributed to the concentration of imbricate thrust sheets above the basement. A broad gravity high which correlates with the positive magnetic anomaly over the Swan Range pluton, is distorted by a 14-mgal gravity minimum anomaly attributed to low-density sediments of Swan River valley.

\section{CONCLUSIONS}

Aeromagnetic and gravity data provide additional dimensions to geologic investigations in the Great Falls-Mission Range area, northwestern Montana. Use of the aeromagnetic data in defining the structural framework and distribution of near-surface crystalline rocks permits more detailed interpretation of the geology, particularly in the mountainous areas of limited access.

In the southern part of the area, magnetic data provide evidence of buried stocks similar to those associated with the ore deposits of the area. The anomaly at the head of Warm Springs Creek (pl. 1, 41) may reflect an intermediate stock that is overlain by Tertiary basalt and andesite.

Magnetic model studies of structure section $A-A^{\prime}$ provide a basis for visualizing a deeply buried irregular basement surface of Precambrian crystalline rocks with much younger plutons possibly projecting into the lower part of the Belt sedimentary rocks.

\section{REFERENCES CITED}

Alpha, A. G., 1955a, The Genou Trend of north central Montana, in Am. Assoc. Petroleum Geologists Rocky Mtn. Sec. Geological record, Feb. 1955: p. 131-138; slightly revised, World Oil, v. 142, no. 1, p. 79-82, 84, 1956.

- 1955b, Tectonic history of north central Montana, in Billings Geol. Soc. Guidebook 6th Ann. Field Conf., Sept. 1955: p. 129-142.

Baadsgaard, Halfdan, Folinsbee, R. E., and Lipson, J. I., 1961, Potassium-argon dates of biotites from Cordilleran granites: Geol. Soc. America Bull., v. 72, no. 5, p. 689-701.

Bally, A. W., Gordy, P. L., and Stewart, G. A., 1966, Structure, seismic data, and orogenic evolution of southern Canadian Rocky Mountains: Bull. Canadian Petroleum Geology, v. 14, no. 3, p. 337-381.

Barnett, V. H., 1916, Geology of the Hound Creek district of the Great Falls coal field, Cascade County, Montana: U.S. Geol. Survey Bull. 641-H, p. 215-231.

Barrell, Joseph, 1907, Geology of the Marysville mining district, Montana, a study of igneous intrusion and contact metamorphism: U.S. Geol. Survey Prof. Paper 57, 178 p.

Bierwagen, E. E., 1964, Geology of the Black Mountain area, Lewis and Clark and Powell Counties, Montana: Princeton Univ. unpub. Ph. D. dissertation, 231 p.; abs., in Dissert. Abs., v. 25, no. 7, p. 4078, 1965.

Bossort, D. O., 1957, Relationship of the Porcupine Hills to early Laramide Movements, in Alberta Soc. Petroleum Geologists Guidebook 7th Ann. Field Conf., Sept. 1957: p. 46-51.

Burfeind, W. J., 1967, A gravity investigation of the Tobacco Root Mountains, Jefferson basin, Boulder batholith, and adjacent areas of southwestern Montana: Bloomington, Ind., Indiana Univ. Ph. D. dissertation, $146 \mathrm{p}$. 
Calkins, F. C., and Jones, E. L., 1931, Economic geology of the region around Mullan, Idaho, and Saltese, Montana: U.S. Geol. Survey Bull. 540, p. 75-86.

Clapp, C. H., 1932, Geology of a portion of the Rocky Mountains of northwestern Montana: Montana Bur. Mines and Geology Mem. 4, $30 \mathrm{p}$.

Cobban, W. A., 1945, Marine Jurassic formations of Sweetgrass arch, Montana: Am. Assoc. Petroleum Geologists Bull., v. 29, no. 9, p. 1262-1303.

Cobban, W. A., Erdmann, C. E., Lemke, R. W., and Maughan, E. K., 1959, Colorado Group on Sweetgrass Arch, Montana, in Billings Geol. Soc. Guidebook 10th Ann. Field Conf., 1959: p. 89-92.

Cook, H. J., 1960, New concepts of late Tertiary major crustal deformations in the Rocky Mountain region of North America: Internat. Geol. Cong., 21st, Copenhagen 1960, Rept., pt. 12, p. 198-212.

Davis, W. E., Kinoshita, W. T., and Robinson, G. D., 1965, Bouguer gravity, aeromagnetic, and generalized geologic map of the western part of the Three Forks Basin, Jefferson, Broadwater, Madison, and Gallatin Counties, Montana: U.S. Geol, Survey Geophys. Inv. Map GP-497, 5 p.

Deiss, C. F., 1935, Cambrian-Algonkian unconformity in western Montana: Geol. Soc. America Bull., v. 46, no. 1, p. 95-124; abs., in Proc. 1933, p. 382-383, 1934.

Dobbin, C. E., and Erdmann, S. E., 1955, Struture contour map of the Montana plains: U.S. Geol. Survey Oil and Gas. Inv. Map OM-178B.

Erdmann, C. E., 1944, Hungry Horse dam and reservoir site, South Fork Flathead River, Flathead County, Montana, with a section on Geophysical investigations, by B. E. Jones, pt. 2 of Geology of dam sites on the upper tributaries of the Columbia River in Idaho and Montana: U.S. Geol. Survey Water-Supply Paper 866-B, p. 37-116.

Evenden, G. I., Frischknecht, F. C., and Meuschke, J. L., 1967, Digital recording and processing of airborne geophysical data, in Geological Survey research 1967: U.S. Geol. Survey Prof. Paper 575-D, p. D79-D84.

Fox, R. D., 1966, Geology and ground-water resources of the Cascade-Ulm area, Montana: Montana Bur. Mines and Geology Bull. 52, 64 p.

Groff, S. L., compiler, 1963, Stratigraphic correlations for Montana and adjacent areas: Montana Bur. Mines and Geology Spec. Pub. 31, 1 sheet.

Gwinn, V. E., 1961, Geology of the Drummond area, central-western Montana: Montana Bur. Mines and Geology Spec. Pub. 21 (Geol. Map 4), with text.

Hammer, Sigmund, 1939, Terrain corrections for gravimeter stations: Geophysics, v. 4. no. 3, p. 184-193.

Harrison, J. E., Kleinkopf, M. D., and Obradovich, J. D., 1971, Tectonic events at the intersection between the Hope fault and Purcell Tranch, northern Idaho: U.S. Geol. Survey Prof. Paper 719 (in press).

Harrison, J. E., Reynolds, M. W., Kleinkopf, M. D., and Pattee, E. C., 1969, Mineral resources of the Mission Mountains primitive area, Missoula and Lake Counties, Montana: U.S. Geol. Survey Bull. 1261-D, 48 p.

Holcombe, T. L., 1963, Geology of the Elk Creek area, Lewis and Clark County, Montana: Missouri Univ. unpub. M.A. thesis.
Hyslop, R. C., 1945, A field method for determining the magnetic susceptibility of rocks: Am. Inst. Mining Metall. Engineers Trans., v. 164 (Geophysics), p. 424-426.

Imlay, R. W., 1957, Paleoecology of Jurassic seas in the western interior of the United States, chap. 17 of Ladd, H. S., ed., Paleoecology: Geol. Soc. America Mem. 67, p. 469-504.

Johns, W. M., 1964, Progress report of geologic investigations in the Kootenai-Flathead area, northwest Montana - [Pt.] 6, Southeastern Flathead County and northern Lake County: Montana Bur. Mines and Geology Bull. $42,66 \mathrm{p}$.

Johnson, R. W., Jr., Henderson, J. R., and Tyson, N. S., 1965, Aeromagnetic map of the Boulder batholith area, southwestern Montana: U.S. Geol. Survey Geophys. Inv. Map GP-538.

Kleinkopf, M. D., and Mudge, M. R., 1968, Aeromagnetic and Bouguer gravity anomalies and related geology of parts of Cascade, Teton, and Lewis and Clark Counties, Montana, in Abstracts for 1967: Geol. Soc. America Spec. Paper 115, p. 429.

Kleinkopf, M. D., Mudge, M. R., and Harrison, J. E., 1968, Aeromagnetic and gravity studies across the northern disturbed belt in northwestern Montana [abs.]: Am. Geophys. Union Trans., v. 49, no. 1, p. 330.

Klepper, M. R., Weeks, R. A., and Ruppel, E. T., 1957, Geology of the southern Elkhorn Mountains, Jefferson and Broadwater Counties, Montana: U.S. Geol. Survey Prof. Paper 292, 82 p. [1958].

Knapp, G. F., 1963, A diorite sill in the Lewis and Clark Range, Montana: Massachusetts Univ. M.S. thesis.

Knopf, Adolph, 1963, Geology of the northern part of the Boulder bathylith and adjacent area, Montana: U.S. Geol. Survey Misc. Geol. Inv. Map I-381.

Lange, S. S., 1963, The geology of the Lewis and Clark Pass area, Lewis and Clark County, Montana: Missouri Univ. unpub. M.A. thesis.

Langton, C. M., 1935, Geology of the northeastern part of the Idaho batholith and adjacent region in Montana: Jour. Geology, v. 43, no. 1, p. 27-60.

Lyons, J. B., 1944, Igneous rocks of the northern Big Belt Range, Montana: Geol. Soc. America Bull., v. 55, no. 4, p. 445-472.

Mansfield, G. R., 1923, Structure of the Rocky Mountains in Idaho and Montana: Geol. Soc. America Bull., v. 34, no. 2, p. 263-284.

McGill, G. E., and Sommers, D. A., 1967, Stratigraphy and correlation of the Precambrian Belt Supergroup of the southern Lewis and Clark Range, Montana: Geol. Soc. America Bull., v. 78, no. 3, p. 343-351.

McMannis, W. J., 1965, Résumé of depositional and structural history of western Montana: Am. Assoc. Petroleum Geologists Bull., v. 49, no. 11, p. 1801-1823.

Melson, W. G., 1964, Geology of the Lincoln area, Montana, and contact metamorphism of impure carbonate rocks: Princeton Univ. unpub. Ph. D. dissertation, 194 p.; abs., in Dissert. Abs., v. 25, no. 10, p. 5864-5865, 1964.

Mudge, M. R., 1965, Bedrock geologic map of the Sawtooth Ridge quadrangle, Teton and Lewis and Clark Counties, Montana: U.S. Geol. Survey Geol. Quad. Map GQ-381. 1966a, Geologic map of the Patricks Basin quadrangle, Teton, and Lewis and Clark Counties, Montana: U.S. Geol. Survey Geol. Quad. Map GQ-453. 
1966b, Geologic map of the Pretty Prairie quadrangle, Lewis and Clark County, Montana: U.S. Geol. Survey Geol. Quad. Map GQ-454.

1966c, Geologic map of the Glenn Creek quadrangle, Lewis and Clark, and Teton Counties, Montana: U.S. Geol. Survey Geol. Quad. Map GQ-499.

1967, Geologic map of the Arsenic Peak quadrangle, Teton, and Lewis and Clark Counties, Montana: U.S. Geol. Survey Geol. Quad. Map GQ-597.

1968, Bedrock geologic map of the Castle Reef quadrangle, Teton and Lewis and Clark Counties, Montana: U.S. Geol. Survey Geol. Quad. Map GQ-711.

1970 , Origin of the disturbed belt in northwestern Montana: Geol. Soc. America Bull., v. 81, no. 2, p. 377-392.

-1971, Pre-Quaternary rocks in the Sun River Canyon area, northwestern Montana: U.S. Geol. Survey Prof. Paper 663-A.

Mudge, M. R., Erickson, R. L., and Kleinkopf, M. D., 1968, Reconnaissance geology, geophysics, and geochemistry of the southeastern part of the Lewis and Clark Range, Montana: U.S. Geol. Survey Bull. 1252-E, 35 p. [1969]

Mudge, M. R., Robinson, G. D., and Eaton, G. P., 1966, Preliminary report on regional aeromagnetic anomalies in northwestern Montana, in Geological Survey research 1966: U.S. Geol. Survey Prof. Paper 550-B, p. B111-B114.

Mudge, M. R., and Sheppard, R. A., 1968, Provenance of igneous rocks in Cretaceous conglomerates in northwestern Montana, in Geological Survey research 1968: U.S. Geol. Survey Prof. Paper 600-D, p. D137-D146.

Nobles, L. H., 1952, Glacial geology of the Mission Valley, western Montana: Harvard Univ. unpub. Ph. D. dissertation, $123 \mathrm{p}$.

Pardee, J. T., 1950, Late Cenozoic block faulting in western Montana: Geol. Soc. America Bull., v. 61, no. 4, p. 359-406.

Pardee, J. T., and Schrader, F. C., 1933, Metalliferous deposits of the greater Helena mining region, Montana: U.S. Geol. Survey Bull. 842, 318 p.

Plouff, Donald, 1966, Digital terrain corrections based on geographic coordinates [abs.]: Geophysics, v. 31, no. 6, p. 1208.

Poulter, G. J., 1959, Structural synthesis of an area in southeastern Granite County, Montana, in Billings Geol. Soc. Guidebook 10th Ann. Field Conf., Aug. 1959: p. 22-33.

Price, R. A., and Mountjoy, E. W., 1970, Geologic structure of the Canadian Rocky Mountains between Bow and Athabasca Rivers-a progress report, in Structure of the southern Canadian Cordillera: Geol. Assoc. Canada Spec. Paper 6, p. 7-25.

Reeside, J. B., Jr., 1957, Paleoecology of the Cretaceous seas of the western interior of the United States, chap. 18 of Ladd, H. S., ed., Paleoecology: Geol. Soc. America Mem. 67 , p. 505-541.

Robinson, G. D., Klepper, M. R., and Obradovich, J. D., 1968, Overlapping plutonism, volcanism, and tectonism in the Boulder batholith region, western Montana, in Studies in volcanology-A memoir in honor. of Howel Williams: Geol. Soc. America Mem. 116, p. $557-576$.
Ross, C. P., Andrews, D. A., and Witkind, I. J., compilers, 1955, Geologic map of Montana: U.S. Geol. Survey, 2 sheets; repr., 1958.

Russell, L. S., 1951, Age of the front-range deformation in the North American Cordillera: Royal Soc. Canada Trans., 3d ser., v. 45, sec. 4, p. 47-69.

Sahinen, U. M., 1959, Metalliferous deposits in the Helena area, Montana, in Billings Geol. Soc. Guidebook 10th Ann. Field Conf., Aug. 1959: p. 129-140.

Schmidt, R. G., 1963, Preliminary geologic map and sections of the Hogan 4 Southeast quadrangle, Lewis and Clark County, Montana: U.S. Geol. Survey Misc., Geol. Inv. Map I-379.

Schmidt, R. G., and Strong, C. P., Jr., 1968, Preliminary geologic map of the Roberts Mountain quadrangle, Lewis and Clark County, Montana: U.S. Geol. Survey Misc. Geol. Inv. Map I-564.

Schmidt, R. G.. Swanson, D. A., and Zubovic, Peter, 1964, Preliminary geologic map and sections of the Hogan 4 Northeast quadrangle, Lewis and Clark and Cascade Counties, Montana: U.S. Geol. Survey Misc. Geol. Inv. Map I-409.

Sloss, L. L., 1950, Paleozoic sedimentation in Montana area: Am. Assoc. Petroleum Geologists Bull., v. 34, no. 3, p. 423-451.

Smedes, H. W., 1966, Geology and igneous petrology of the northern Elkhorn Mountains, Jefferson and Broadwater Counties, Montana: U.S. Geol. Survey Prof. Paper 510, $116 \mathrm{p}$.

Smith, R. B., 1967, A regional gravity survey of western and central Montana: Salt Lake City, Utah, Utah Univ. $\mathrm{Ph}$. D. dissertation, $140 \mathrm{p}$.

1970, Regional gravity survey of western and central Montana: Am. Assoc. Petroleum Geologists Bull., v. 54, no. 7, p. 1172-1183.

Sommers, D. A., 1966, Stratigraphy and structure of a portion of the Bob Marshall wilderness area, northwestern Montana: Massachusetts Univ. unpub. Ph. D. dissertation, 234 p.; abs., in Dissert. Abs., v. 27, no. 8, p. 2751-B, 1967.

Stebinger, Eugene, 1918, Oil and gas geology of the Birch Creek-Sun River area, northwestern Montana: U.S. Geol. Survey Bull. 691-E, p. 149-184.

Tilling, R. I., Klepper, M. R., and Obradovich, J. D., 1968, $\mathrm{K}$-Ar ages and time span of emplacement of the Boulder batholith, Montana: Am. Jour. Sci., v. 266, no. 8, p. 671-689.

Vacquier, Victor, Steenland, N. C., Henderson, R. G., and Zietz, Isidore, 1951, Interpretation of aeromagnetic maps: Geol. Soc. America Mem. 47, 151 p.

Viele, G. W., 1960, The geology of the Flat Creek area, Lewis and Clark County, Montana: Utah Univ. unpub. Ph. D. dissertation, 292 p.; abs., in Dissert. Abs., v. 21, no. 4, p. 853,1960 .

Viele, G. W., and Harris, F. G. 3d, 1965, Montana Group stratigraphy, Lewis and Clark County, Montana: Am. Assoc. Petroleum Geologists Bull., v. 49, no. 4, p. 379-417.

Walcott, C. D., 1906, Algonkian formations of northwestern Montana: Geol. Soc. America Bull., v. 17, p. 1-28.

Weed, W. H., 1899, Description of the Little Belt Mountains quadrangle [Montana]: U.S. Geol. Survey Geol. Atlas, Folio 56, 11 p., 4 maps. 
Woollard, G. P., 1958, Results for a gravity control network at airports in the United States: Geophysics, v. 23, no. 3, p. 533.

Woollard, G. P., chm., and Joesting, H. R., coordinator, 1964, Bouguer gravity anomaly map of the United States (exclusive of Alaska and Hawaii): U.S. Geol. Survey, 2 sheets.
Zietz, Isidore, and Andreasen, G. E., 1967, Remanent magnetization and aeromagnetic interpretation, in Mining geophysics-v. 2, Theory: Tulsa, Okla., Soc. Explor. Geophysicists, p. 569-590.

Zietz, Isidore, and Henderson, R. G., 1956, A preliminary report on model studies of magnetic anomalies of threedimensional bodies: Geophysics, v. 21, no. 3, p. 794-814. 